\title{
The Impact of Mobile Learning on Listening Anxiety and Listening Comprehension
}

\author{
Mehrak Rahimi ${ }^{1}$ \& Elham Soleymani ${ }^{1}$ \\ ${ }^{1}$ Shahid Rajaee Teacher Training University, Tehran, Iran \\ Correspondenc: Mehrak Rahimi, English Department, Faculty of Humanities, Shahid Rajaee Teacher Training \\ University, Lavizan, 1678815811, Tehran, Iran. E-mail: mehrakrahimi@yahoo.com
}

Received: June 15, 2015 Accepted: September 19, 2015 Online Published: September 21, 2015

doi:10.5539/elt.v8n10p152 URL: http://dx.doi.org/10.5539/elt.v8n10p152

\begin{abstract}
This study aimed at investigating the impact of mobile learning on EFL learners' listening anxiety and listening comprehension. Fifty students of two intermediate English courses were selected and sampled as the experimental $(n=25)$ and control $(n=25)$ groups. Students' entry level of listening anxiety was assessed by foreign language listening anxiety questionnaire and their listening comprehension was assessed by Key English Test (KET) prior to the study. For one semester the experimental group did their listening activities by using podcasts listened to on their mobile phones and/or portable digital media players. Meanwhile the control group used their desktop computers to do their listening activities. The results of data analysis showed that listening anxiety of the experimental group reduced significantly after the experiment. Further, a significant difference between the experimental and control groups' listening comprehension was found in favor of the experimental group at the end of the experiment.
\end{abstract}

Keywords: listening comprehension, mobile learning, podcast, listening anxiety

\section{Introduction}

Listening is an important language skill that contributes to the internalization of language rules and facilitates the emergence of other language skills (Vandergrift, 1997). Although listening might apparently be seen as a passive process, it is actually a complex and active process of interpretation of what listeners hear and what they already know (Vandergrift, 1999). Listening is an interactive process of recognition, perception, and understanding of the oral input (Vandergrift, 2002) and "an intention to complete a communication" (Rost, 2002, p. 40).

Since listening is an unobservable skill, it is the least explicit language skill (Vandergrift, 2004) and second language learners often regard it as the most complicated skill to learn and master (Graham, 2003). Finding reasons of why listening is such a difficult skill is not an easy task and it seems that the answer is taking shape as listening theories and practices are evolving. Listening has been reported to be a difficult skill due to the features inherent in oral input such as phonological and lexical features (Flowerdew, 1994); reduced forms (Ito, 2001); invisible word boundaries (Weber \& Cutler, 2006); and irregular pauses, false starts, and intonation patterns (Gilmore, 2007). However, listening can be difficult for some listeners due to their limited processing skill (Buck, 2001) and lack of control over the speech rate (Osada, 2004), or inadequate knowledge of vocabulary, topics, and accents (Buck, 2001).

Listeners' emotional side seems to be among the most important factors that can influence the way the processing of information takes place. One of such traits that can hinder the understanding of oral input is listening anxiety or "the type of anxiety experienced by language learners in situations that require listening" (Bekleyen, 2009). Listening anxiety is believed to receive less attention than other facets of language anxiety because listening was thought to be a passive skill for a very long time and it was thus difficult to be assessed or identified by teachers or researchers (Ghapanchi \& Golparvar, 2012).

The characteristics of listening task and the condition of listening are also considered to be important factors affecting listening comprehension. As a result, there has been a surge of interest to investigate the role of different types of listening instruction and materials in listening comprehension (e.g., Goh, 2000). By the advent 
of technological tools, the experts' attention has been shifted to studying the role of computer-based learning environment on both decreasing language learning anxiety and increasing teaching/learning efficiency. Recently, Web 2.0 affordances (wikis, podcasts, social networking, and blogs) have been found to impact language learning in general and the development of language skills in particular. While Wikis and blogging have been reported to be useful in teaching and practicing written language skills (e.g., Li, 2011), podcasting has been found to be beneficial in improving oral language skills (e.g., Kim, 2011) especially listening (Rosell-Aguilar, 2007). What seems to be neglected in podcasting research, however, is its contribution to mobile learning (m-learning), that is, learning anywhere at any time (Evans, 2008). Podcasts have significantly contributed to taking m-learning to the next generation as they extend learning out of the classroom situation (McKinney, Dyck, \& Luber, 2009). Podcasting enables learners to do the listening activities at their own pace and at suitable time and place, as well as practicing individually. In this way, learners are provided with informal language learning out of the classroom while flexibility, portability, time-shifting and multitasking are added to learning (Thorne \& Payne, 2005).

It is thus logical to argue that the type of listening task podcasts provide listeners with and the condition of listening practice they offer can lower EFL learners' listening anxiety as listening processing can take place more efficiently with the help of technology. The purpose of this study is to investigate the impact of listening to podcasts on mobile devices -in comparison to desktop personal computers- on EFL learners' listening anxiety and listening comprehension. Research questions of the study are as follows:

1). Does mobile learning have any impact on EFL learners' listening anxiety?

2). Does mobile learning have any impact on EFL learners' listening comprehension?

\subsection{Listening Anxiety}

Listening comprehension complexity can frequently cause irritation and anxiety among second or foreign language learners (Graham, 2006). Anxiety is one of the vital individual differences that is defined as "the subjective feeling of tension, apprehension, nervousness, and worry associated with an arousal of the autonomic nervous system" (Horwitz, Horwitz, \& Cope, 1986, p. 125). Concerning the impact of anxiety on foreign language learning, two types of anxiety exist, facilitating or debilitating. Facilitating anxiety can act as a motivator of the learners (Ellis, 1994); while debilitating anxiety linked to language skills like listening (McIntyre \& Gardner, 1994 cited in Gregersen, 2007) causes learners to avoid the language learning process (Zhang, 2001). Research shows a significant negative correlation between foreign language listening anxiety and listening proficiency of the learners (Kim, 2000). Anxious learners lack confidence and are not able to spot language errors (Gregerson, 2003); can be distracted easily; have concentration problems and might have limited short-term memory capacities (Piechurska-Kuciel, 2008); might forget previously learned materials; and tend to be passive in classroom activities in comparison to their less anxious peers (Horwitz, Horwitz, \& Cope, 1986).

Listening anxiety affects listening comprehension as well as listening ability (Horwitz \& Cope, 1986) mainly when the text is incomprehensible to the listener and thus can hinder students' success in listening (Ozbay, 2010). This type of anxiety which is associated with listening tasks is called listening anxiety. Learners' listening anxiety varies according to their level of ability in foreign language listening (Mills, Pajares, \& Herron, 2006). The reasons of listening anxiety might be attributed to the problematic nature of listening (Christenberry, 2003), nature of the speech, level of difficulty, lack of clarity, lack of visual support, lack of repetition, spontaneous speech, fast speech, and unfamiliar accents/topics (Vogely, 1998). Authenticity of the listening text and external environmental factors such as noise, inaudibility, and incomprehensibility of the listening material can also affect emotions of the listeners (Gonen, 2009). Also, facing a difficult or new listening situation and misunderstanding the rest of the aural input because of not hearing some words have been identified as sources of listening anxiety (Kim, 2000).

Learners might encounter listening anxiety in three stages: pre-listening which is linked to varied distractions and not being familiar with the topic; during listening and post-listening when anxiety is created as a result of listener's failure to make a connection between new and previous knowledge (Tobias, 1986). If students improve their listening skills, all the negative influences of anxiety start to disappear (MacIntyre \& Gardner, 1989). Hence, the teachers would try to help the learners conquer their listening anxiety by applying new approaches to teaching and/or providing less anxiety provoking learning environments and listening tasks. 


\subsection{Podcasting Technology}

The second-generation of Web, known as Web 2.0, has provided new ways of online communication (Warschauer \& Grimes, 2007) with its exclusive tools for communication, interaction, and collaboration (Bennett et al., 2012). Web 2.0 concentrates on the extensive applications such as blogs, video sharing, social networking and podcasting to connect the users to web authoring rather than just making use of it (Anderson, 2007). Due to the educational benefits and potentials of Web 2.0 technologies and affordances, Web 2.0 has become enormously popular around the world and is used extensively by teachers and students.

Among web 2.0 tools podcasts have been found to be very useful for educational purposes (O'Bannon et al. 2011). The word podcast is a combination of the words iPod (a popular portable media player) and broadcast (Rosell-Aguilar, 2007), and consists of media files that can be distributed via the Internet and played on computers and handheld devices such as cell phones, iPods, or other digital audio players (Mathieu, 2009). Podcasts may be delivered in audio formats only or in enhanced formats, audio and video. Video podcasts are audio-visual files that are distributed in a digital format through the Internet using personal computers or mobile devices (Kay \& Kletskin, 2012). They are perhaps best known to students through the YouTube website where over three billon clips are viewed each day (Henry, 2011).

Podcasts supply educational content in a format that is fitting to the student needs as it is available whenever and wherever the student wants (Lazzari, 2009). The mobility of learning is considered as an advantage of podcasting although students can also choose to listen to podcasts on a computer in a "study-like" environment (McKinney, \& Page, 2009). Podcasts can be used for different purposes such as substituting classroom lectures, supplementing additional materials for classroom teachings, and raising creativity and collaboration among students (Rahimi \& Katal, 2012). Two types of podcasts frequently used in language education (Rosell-Aguilar, 2007) are:

- Authentic podcasts: they have authentic content that are produced and used by native speakers such as news.

- Language courses podcasts: they can be categorized into stand-alone language courses and add on materials for particular classes or independent audience.

Research shows that podcasts have several educational benefits. Podcasts can be easily published, subscribed, and used across multiple settings and they can facilitate recording and distributing teachers' notes and lectures as well as students' projects and interviews (Campbell, 2005). They may provide oral history archiving and on-demand distribution and foster the integration of in-class and out-of-class activities (Meng, 2005). In language classes they make authentic foreign language materials available for download (Thorne \& Payne, 2005); combine the advantages of radio and cassettes (McLoughlin \& Lee, 2007); and increase creativity, independent learning and collaboration (Clothey \& Schmitt, 2008). Podcasts empower students by giving them opportunities to create and publish for a real audience (Salmon et al., 2008), create intrinsic and extrinsic motivation (O-Bryan \& Hegelheimer, 2007), provide students with group and personal feedback (France \& Wheeler, 2007), facilitate revisiting of teaching/learning materials (Brittain et al., 2006), and encourage active learning (Jenkins \& Lynch, 2006).

The new generation of students who has grown up and lived with digital technology can use podcasts easily and efficiently on their portable digital tools (such as cell phones, MP3, MP4) to promote mobile learning. Podcasts allow students to access educational materials at home, while commuting to university or work, or doing any activity they choose (Prensky, 2001). They can play the recordings at any time rather than be confined to fixed study times (Townend, 2005). This impacts students' motivation, lowers their fear of learning, and possibly increases their learning outcome.

\section{Method}

\subsection{Participants}

Fifty intermediate EFL learners participated in this study. Those participants who had access to portable media player tools (such as mobile phones, MP3, MP4) to listen to audio files anywhere and anytime were put in the experimental group $(\mathrm{n}=25)$. Those who did the listening tasks on their desktop computers were put in the control group $(n=25)$. The participants were all female and ranged in age between 12 and 30 (mean=17.94, $\mathrm{SD}=6.60)$. 


\subsection{Instruments}

Two instruments were used in this study:

- Foreign Language Listening Anxiety Questionnaire

- $\quad$ Key English Test (KET)

2.2.1. Foreign Language Listening Anxiety Questionnaire

Foreign Language Listening Anxiety Questionnaire (FLLAQ) (Kimura, 2008) was used to assess learners' language listening anxiety. The scale was translated into Persian and then back-translated to check the clarity and accuracy of its wording. The scale has 26 items that are categorized into 3 factors including emotional anxiety, worry and anticipatory fear.

The respondents were asked to rate themselves regarding how they felt anxious when they listened to English texts on a six-point Likert scale including 1 'never', 2 'rarely', 3 'seldom', 4 'often', 5 'usually', and 6 'always'. The reliability of the scale was estimated to be 0.91 for the whole scale and $0.85,0.86$, and 0.80 for the subscales respectively.

\subsubsection{Key English Test}

The Key English Test (KET) examination is a type of examination developed by Cambridge ESOL called the Cambridge Main Suite (KET, 2009). KET has three main sections including: reading and writing, listening, and speaking.

For the purpose of this study, the listening part of KET was used to assess participants' listening ability before and after the study. The listening part has 5 parts and 25 items; and its administration takes around 35 minutes.

The reliability of the scale was calculated using KR20 and found to be .86 .

\subsection{Procedure}

Two groups of students were selected based on their access to portable digital devices or desktop computers to listen to audio files in the format of podcasts. Both groups listened to 12 podcasts to do the listening activities of their course for twelve weeks. The students were asked to do a variety of exercises based on the audio files. The experimental group downloaded and saved the podcasts on their portable devices and thus listened to them anywhere at any time. The control group listened to the files on their desktop computers so they did not experience mobile learning.

\section{Results}

\subsection{M-learning and Listening Anxiety}

Table 1 summarizes the mean scores of both groups' listening anxiety after the experiment.

Table 1. Descriptive statistics of listening anxiety posttest

\begin{tabular}{lll}
\hline Groups & Mean & SD \\
\hline Control group $(\mathrm{n}=25)$ & 3.912 & .841 \\
Experimental group $(\mathrm{n}=25)$ & 2.903 & .488 \\
\hline
\end{tabular}

As Table 1 shows, the experimental group had lower mean score on anxiety questionnaire after the experiment (Mean=2.903) in comparison to the control group (Mean=3.912). In order to answer research question 1 and test whether this difference was statistically significant, a one-way between-groups analysis of covariance (ANCOVA) was conducted. Preliminary checks were conducted to ensure that there was no violation of the assumptions of normality, linearity, homogeneity of variances, homogeneity of regression slopes, and reliable measurement of the covariate. Participants' scores on anxiety questionnaire pretest were used as the covariate in this analysis. 
Table 2. The result of ANCOVA

\begin{tabular}{lllllll}
\hline Source & Type III Sum of Squares & df & Mean Square & F & Sig. & Partial Eta Squared \\
\hline Corrected Model & 19.745 & 2 & 9.873 & 29.488 & .000 & .557 \\
Intercept & 2.735 & 1 & 2.735 & 8.169 & .006 & .148 \\
FLLAQ pretest & 7.001 & 1 & 7.001 & 20.912 & .000 & .308 \\
Group & 12.894 & 1 & 12.894 & 38.511 & .000 & .450 \\
Error & 15.736 & 47 & .335 & & & \\
Total & 616.163 & 50 & & & & \\
Corrected Total & 35.481 & 49 & & & & \\
\hline
\end{tabular}

As Table 2 shows, the result of ANCOVA revealed that there was a significant difference between two groups in anxiety questionnaire posttest $[\mathrm{F}(1,47)=38.511 ; p=.000$; partial eta squared $=.450]$. Accordingly, the conclusion can be drawn that the experience of mobile learning by podcasts has caused a lower level of listening anxiety in comparison to conventional computer-assisted learning that does not focus on using mobile devices in the process of learning and doing listening tasks.

\subsection{M-learning and Listening Comprehension}

Table 3 presents the mean scores of both groups' listening comprehension posttests.

Table 3. Descriptive statistics of listening comprehension posttest

\begin{tabular}{lll}
\hline Groups & Mean & SD \\
\hline Control group $(\mathrm{n}=25)$ & 13.920 & 3.787 \\
Experimental group $(\mathrm{n}=25)$ & 17.600 & 3.535 \\
\hline
\end{tabular}

As Table 3 shows, the mean score of the experimental group is higher than (mean=17.600) that of the control group (mean=13.920) in listening posttest. To compare the means of both groups' listening posttests and to test whether their difference was statistically significant due to mobile learning intervention, a one-way between-groups analysis of covariance (ANCOVA) was conducted. Preliminary checks were conducted to ensure that there was no violation of the assumptions of normality, linearity, homogeneity of variances, homogeneity of regression slopes, and reliable measurement of the covariate. The scores on the pretests were treated as covariates to control for preexisting differences between the groups.

Table 4. The result of ANCOVA

\begin{tabular}{lllllll}
\hline Source & Type III Sum of Squares & df & Mean Square & F & Sig. & Partial Eta Squared \\
\hline Corrected Model & $667.198 \mathrm{a}$ & 2 & 333.599 & 82.861 & .000 & .779 \\
Intercept & 21.795 & 1 & 21.795 & 5.414 & .024 & .103 \\
KET pretest & 455.018 & 1 & 455.018 & 113.020 & .000 & .706 \\
Group & 119.974 & 1 & 119.974 & 29.800 & .000 & .388 \\
Error & 189.222 & 47 & 4.026 & & & \\
Total & 12931.000 & 50 & & & & \\
Corrected Total & 856.420 & 49 & & & & \\
\hline
\end{tabular}

As Table 4 shows, the result of ANCOVA revealed that there was a significant difference between two groups in 
listening posttest $[\mathrm{F}(1,47)=29.800 ; p=.000$; partial eta squared $=.388]$ in favor of the experimental group. Accordingly, the conclusion can be drawn that mobile learning intervention has caused a higher level of listening comprehension in comparison to conventional computer-assisted learning that does not focus on using mobile devices in the process of learning and doing listening tasks.

\section{Discussion}

The aim of the current study was investigating the impact of mobile learning on EFL learners' listening anxiety and listening comprehension.

The findings revealed that doing listening activities by mobile devices has a significant effect on reducing language listening anxiety. The finding is in agreement with other studies and suggests that mobile learning and technology-based intervention contribute to a reduction in student anxiety as more confidence is generated as a result of increased comprehension ability (Evans, 2008). Podcasts provide flexible and mobile learning opportunities for students (Chinnery, 2006) that reduce their fear of listening and its difficulty and have huge potential in enhancing second language learners' listening skills (Stanley, 2005).

Traditional face to face classroom learning is characterized with certain features including a priori syllabus, fixed context of teaching, and predictable hours of study as well as principal components of one teacher, a textbook, and teaching methodology that is mostly based on class presence. Classroom variables such as uninteresting learning materials and boring teaching methodologies are found to be the sources of demotivation as "amotivated people feel a lack of competence or control over their external environments" (Falout, Elwood, Hood, 2009, p. 404). Students' demotivation can create negative attitudes towards the subject and the learning in general. Lack of motivation and negative attitudes can amplify worries and anxieties of learners in doing their class activities. Mobile learning, on the other hand, creates quick and simple interactions with people and technology; provides flexible materials that can be accessed in different contexts; and takes advantage of mobile devices not only to deliver learning but also to facilitate it (Sharples, Sánchez, Milrad, \& Vavoula, 2009, p. 4). Due to the communicative nature of language learning, these features contribute to more relaxed learning experiences and thus motivate language learners to pursue difficult and challenging tasks like listening to a foreign language.

The findings also showed that mobile learning can have a significant effect on learners' improvement of listening comprehension ability which can be supported by the literature (e.g., Burston, 2013). The reason of this finding might be justified by the transitory nature of mobile learning and the point that students can listen to the material anytime and anywhere they wish (Goh, 2000) even outside the classroom (Hadley, 2001). In this ways there would be no time limitation for doing activities or assignments and language learners can do them at their own pace (Hew, 2009). Individualized instruction promotes learning responsibility and self-regulation among learners and guarantees successful learning and better accomplishment.

Listening comprehension has been found to be a difficult skill for foreign language learners. The difficulty of listening comprehension is related basically to the way the aural input is processed, as both bottom-up and top-down processing are involved in this complex process. While computer-based learning environments have been found to contribute to more successful listening, mobile learning has certain unique features that make the whole task less threatening and more accomplishable. These include:

(a) Portability - can take the computer to different sites and move around within a location.

(b) Social interactivity - can exchange data and collaborate with other people face to face.

(c) Context sensitivity - can gather data unique to the current location, environment, and time, including both real and simulated data.

(d) Connectivity - can connect handhelds to data collection devices, other handhelds, and to a common network that creates a true shared environment.

(e) Individuality - can provide unique scaffolding that is customized to the individual's path of investigation (Klopfer \& Squire, 2008, as cited in Squire \& Dikkers, 2012, p. 447).

The findings of the study corroborate other studies that the availability and affordability of portable media players among the young generation have paved the way for integrating podcasting technology into language classes and promoting m-learning. M-learning helps students use their mobile devices to go through the activities and tasks on-the-go. In case of language learning this feature of mobile learning is a more practical help, as "extending language learning outside of classroom time, especially where in-class language practice time is 
limited, is essential to language acquisition" (Kennedy \& Levy, 2009, cited in Steel, 2012, p. 2).

Further, mobile learning and podcasts can provide comprehensible input for the learners and thus increase their motivation (Krashen, 1985) and consequently promote their listening comprehension. This supports the role of podcasting in providing the added and informal language learning without increasing classroom time (Palalas, 2011).

\section{Conclusions}

Language learners are often overwhelmed by too much anxiety involved in the process of learning a foreign language and its skills. Listening skill as a highly anxiety provoking skill is one of the essential skills which need to be master and used for communication. The results of this paper indicated that mobile learning did have a significant effect on the listening comprehension ability of experimental group, and reduced the listening anxiety level of language learners. The study offers practical solutions for tackling emotional problems of EFL listeners such as practicing listening skill with cell phones and having extensive listening in the form of podcasts to be listened to at home or wherever the students like. When language learners have the opportunity to listen in informal situations without time limitation pressure, they are more motivated to listen to English and thus practice more.

The findings underline the need to use the state-of-the-art technologies in teaching and learning a foreign language. More follow-up research is however required to find the impact of other mobile learning technologies on the development of language skills and components. The future studies are urged to utilize mixed methods research design to gather both qualitative and quantitative data to probe into the effectiveness of utilizing mobile devices in language teaching/learning on the development of language ability and language learning motivation.

\section{References}

Anderson, P. (2007). What is Web 2.0? Ideas, technologies and implications for education. US: Technical Report, JISC.

Bekleyen, N. (2009). Helping teachers become better English students: Causes, effects, and coping strategies for foreign language listening anxiety. System, 37, 664-675. http://dx.doi.org/10.1016/j.system.2009.09.010

Bower, M., Hedberg, J., \& Kuswara, A. (2009). Conceptualizing Web 2.0 enabled learning designs. Same places, different spaces. Proceedings ASCILITE Auckland 2009. Retrieved from http://www.ascilite.org.au/conferences/auckland09/procs/bower.pdf.

Brittain, S., Glowacki, P., Van Ittersum, J., \& Johnson, L. (2006). Podcasting lectures: Formative evaluation strategies helped identify a solution to a learning problem. Education Quarterly, 3, 24-31.

Buck, G. (2001). Assessing listening. Cambridge: Cambridge University Press. http://dx.doi.org/10.1017/CBO9780511732959

Burston, J. (2013). Mobile Assisted Language Learning: A selected annotated bibliography of implementation studies 1994-2012. Language Learning \& Technology, 17(3), 157-225.

Campbell, G. (2005). There's something in the air: Podcasting in education. Educause Review, 40(6), 32-47.

Chinnery, G. M. (2006). Going to the MALL: Mobile Assisted Language Learning. Language Learning \& Technology, 10(1), 9-16.

Christenberry, B. (2003). Listening comprehension in the foreign language classroom. Retrieved from $\mathrm{http} / / /$ langlab.uta.edu/german/lana.rings/fall01 gradstudents/2001 paperchristenberry.htm

Clothey, R., \& Schmitt, C. (2008). Education in motion: Innovating with iPods. In C. Montgomerie, \& J. Seale (Eds.), Proceedings of ED-MEDIA (pp. 629-639). VA: Chesapeake.

Ellis, R. (1994). The study of second language acquisition. Oxford University Press.

Evans, C. (2008). The effectiveness of m-learning in the form of podcast revision lectures in higher education. Computers \& Education, 50, 491-498. http://dx.doi.org/10.1016/j.compedu.2007.09.016

Falout, J, Elwood, J., \& Hood, M. (2009). Demotivation: Affective states and learning outcomes. System, 37, 403-417. http://dx.doi.org/10.1016/j.system.2009.03.004

Flowerdew, J. (1994). Academic listening: Research perspectives. Cambridge: Cambridge University Press. 
France, D., \& Wheeler, A. (2007). Reflections on using podcasting for student feedback. Gees Planet, 18, 9-11. http://dx.doi.org/10.11120/plan.2007.00180009

Ghapanchi, Z., \& Golparvar, E. (2012). Foreign language listening anxiety in Iranian EFL context. International Journal of Social Sciences and Humanities, 1, 16-22.

Gilmore, A. (2007). Authentic materials and authenticity in foreign language learning. Language Teaching, 40, 97-118. http://dx.doi.org/10.1017/S0261444807004144

Goh, C. C. (2000). A cognitive perspective on language learners' listening comprehension problems. System, 28 , 55-75. http://dx.doi.org/10.1016/S0346-251X(99)00060-3

Gonen, M. (2009). The relationship between FL listening anxiety and foreign language listening strategies: The case of Turkish EFL learners. Proceedings of the 5th WSEAS/IASME International Conference on Educational Technologies (EDUTE'09).

Graham, S. (2003). Learner strategies and advanced level listening comprehension. Language Learning Journal, 28, 64-69. http://dx.doi.org/10.1080/09571730385200221

Graham, S. (2006). Listening comprehension: The learners' perspective. System, 34, 165-182. http://dx.doi.org/10.1016/j.system.2005.11.001

Gregerson, T. S. (2003). To err is human: A reminder to teachers of language-anxious students. Foreign Language Annals, 36(1), 25-32. http://dx.doi.org/10.1111/j.1944-9720.2003.tb01929.x

Gregersen, T. S. (2007). Breaking the code of silence: A study of teachers' nonverbal decoding accuracy of foreign language anxiety. Language Teaching Research, 11(2), 209-221. http://dx.doi.org/10.1177/1362168807074607

Hadley, A. O. (2001). Teaching language in context. Boston, MA: Heinle \& Heinle.

Henry, A. (2011). You Tube hits 3 billion views per day, 48 hours of video uploaded per minute. Retrieved from http://www.geek.com/articles/news/youtube-hits-3-billion-views-per-day-48-hours-of-video-uploaded-perminute-20110526/

Hew, K. (2009). Use of audio podcast in K-12 and higher education: A review of research topics and methodologies. Educational Technology Research and Development, 57(3), 333-357. http://dx.doi.org/10.1007/s11423-008-9108-3

Horwitz, E. K., Horwitz, M. B., \& Cope J. A. (1986). Foreign language classroom anxiety. Modern Language Journal, 70, 125-132. http://dx.doi.org/10.1111/j.1540-4781.1986.tb05256.x

Ito, Y. (2001). Effect of reduced forms on ESL learners' input-intake process. Second Language Studies, 20(1), 99-124.

Jenkins, M., \& Lynch, K. (2007). I want to tell you a story. Paper presented at the 23rd annual ASCILITE conference, Sydney, Australia, 3-6 December 2007. Retrieved from http://www.ascilite.org.au/conferences/ sydney06/proceeding/pdf_papers/p74.pdf

Kay, R., \& Kletskin, I. (2012). Evaluating the use of problem-based video podcasts to teach mathematics in higher education. Computer \& Education, 59, 619-627.

KET. (2009). Cambridge Key English Test 4. Cambridge: Cambridge University Press.

Kim, J. H. (2000). Foreign language listening anxiety: A study of Korean students learning English. Unpublished doctoral dissertation, University of Texas, Austin.

Kim, D. (2011). Incorporating podcasting and blogging into a core task for ESOL teacher candidates. Computers \& Education, 56(3), 632-641.

Kimura, H. (2008). Foreign language listening anxiety: Its dimensionality and group differences. JALT Journal, 30, 137-196.

Krashen, S. D. (1985). The input hypothesis: Issues and implications. New York: Longman.

Lazzari, M. (2009). Creative use of podcasting in higher education and its effect on competitive agency. Computers \& Education, 52, 27-34. http://dx.doi.org/10.1016/j.compedu.2008.06.002

Li, M. (2011). Use of wikis in second/foreign language classes: A literature review. CALL-EJ, 13, 17-35. 
MacIntyre, P. D., \& Gardner, R. C. (1989). Anxiety and second language learning: Toward a theoretical clarification. Language Learning, 39(2), 251-275. http://dx.doi.org/10.1111/j.1467-1770.1989.tb00423.x

Mathieu, J. (2009). Blogs, podcasts, and wikis: The new names in information dissemination. American Dietetic Association, 107, 553-555. http://dx.doi.org/10.1016/j.jada.2007.02.027

McKinney, D., Dyck, J. L., \& Luber, E. S. (2009). ITunes university and the classroom: Can podcasts replace professors? Computers \& Education, 52, 617-623. http://dx.doi.org/10.1016/j.compedu.2008.11.004

McKinney, A. A., \& Page, K. (2009). Podcasts and videostreaming: Useful tools to facilitate learning of Pathophysiology in undergraduate nurse education. Nurse Education in Practice, 9, 372-376. http://dx.doi.org/10.1016/j.nepr.2008.11.003

McLoughlin, C., \& Lee, M. (2007). Listen and learn: A systematic review of the evidence that podcasting supports learning in higher education. In C. Montgomerie, \& J. Seale (Eds.), Proceedings of ED-MEDIA (pp. 1669-1677). VA: Chesapeake.

Meng, P. (2005). Podcasting and vodcasting: A white paper. Retrieved from http://edmarketing.apple.com/adcinstitute/wp-content/Missouri_Podcasting_White_Paper.pdf

Mills, N., Pajares, F., \& Herron, C. (2006). A reevaluation of the role of anxiety: Self-efficacy, anxiety, and their relation to reading and listening proficiency. Foreign Language Annals, 39, 276-295. http://dx.doi.org/10.1111/j.1944-9720.2006.tb02266.x

O’Bannon, B. W., Lubke, J. K., Beard, J. L., \& Britt, V. G. (2011). Using podcasts to replace lecture: Effects on $\begin{array}{lllll}\text { student } \quad \text { achievement. Computers } \quad \& \quad \text { Education, } & \text { 57, }\end{array}$ http://dx.doi.org/10.1016/j.compedu.2011.04.001

Osada, N. (2004). Listening comprehension research: A brief review of the past thirty years. Dialogue, 3, 53-66.

Ozbay, M. (2010). Turkish education neglected area: Listening training. Turkish language teaching articles (pp. 191-201). Ankara: Oncu Book.

Palalas, A. (2011). Mobile-Assisted Language Learning: Designing for your students. In S. Thouësny, \& L. Bradley, (Eds.), Second language teaching and learning with technology. Research-publishing.net: Voillans. $\mathrm{http}: / / \mathrm{dx}$.doi.org/10.14705/rpnet.2011.000007

Piechurska-Kuciel, E. (2008). Language anxiety in secondary grammar school students. Opole: Wydawnictwo Uniwersytetu Opolskiego.

Prensky, M. (2001). Digital natives, digital immigrants. On the Horizon, 9, 1-6. http://dx.doi.org/10.1108/10748120110424816

Rahimi, M., \& Katal, M. (2012). The role of metacognitive listening strategies awareness and podcast-use readiness in using podcasting for learning English as a foreign language. Computers in Human Behavior, 28, 1153-1161. http://dx.doi.org/10.1016/j.chb.2012.01.025

Rosell-Aguilar, F. (2007). Top of the Pods-In search of a podcasting "Pedagogy" for language learning. Computer Assisted Language Learning, 20, 471-492. http://dx.doi.org/10.1080/09588220701746047

Rost, M. (2002). Teaching and researching listening. London: Longman.

Salmon, G., Mobbs, R., Edirisingha, P., \& Dennett, C. (2008). Podcasting technology. In G. Salmon, \& P. Edirisingha (Eds.), Podcasting for learning in universities (pp. 20-32). New York: Open University Press.

Squire, K., \& Dikkers, S. (2012). Amplifications of learning: Use of mobile media devices among youth. Convergence: The International Journal of Research into New Media Technologies, 18, 445-464. http://dx.doi.org/10.1177/1354856511429646

Sharples, M., Arnedillo-Sánchez, I., Milrad, M., \& Vavoula, G. (2009). Mobile learning: Small devices, big issues. In N. Balacheff, N., Ludvigsen, S., de Jong, T., Lazonder, A., Barnes, \& L. Montandon (Eds.). Technology-enhanced learning (pp. 233-249). Heidelberg: Springer.

Stanley, G. (2005). An Introduction to podcasting for EFL/ESL teachers. Podcast posted on BLOG-EFL website. Retrieved from http://blog-efl.blogspot.com

Steel, C. (2012). Fitting learning into life: Language students' perspectives on benefits of using mobile apps. 
Proceedings of ascilite 2012, Future Challenges Sustainable Future. Wellington, New Zealand. http://www.ascilite.org.au/conferences/wellington12/2012/images/custom/steel\%2c_caroline_fitting_learnin g.pdf

Thorne, S., \& Payne, J. (2005). Evolutionary trajectories, Internet-mediated expression, and language education. CALICO, 22, 371-397.

Tobias, S. (1986). Anxiety and cognitive processing of instruction. In Schwarzer R (Ed.). Self-related cognition in anxiety and motivation. New Jersey: Erlbaum Hillsdale.

Townend, N. (2005). Podcasting in higher education. Viewfinder, 61, 1-4.

Vandergrift, L. (1997). The comprehension strategies of second language (French) listeners: A descriptive study. Foreign Language Annals, 30(3), 387-409. http://dx.doi.org/10.1111/j.1944-9720.1997.tb02362.x

Vandergrift, L., (1999). Facilitating second language listening comprehension: Acquiring successful strategies. ELT Journal, 53, 6. http://dx.doi.org/10.1093/elt/53.3.168

Vandergrift, L., (2002). Listening: Theory and practice in modern foreign language competence. Retrieved from http://www.llas.ac.uk/resources/goodpractice.aspx?resourceid=67

Vandergrift, L. (2004). Listening to learn or learning to listen? Annual Review of Applied Linguistics, $24,3-25$. http://dx.doi.org/10.1017/S0267190504000017

Vogely, A. J. (1998). Listening comprehension anxiety: Students' reported sources and solutions. Foreign Language Annals, 31(1), 67-80. http://dx.doi.org/10.1111/j.1944-9720.1998.tb01333.x

Warschauer, M., \& Grimes, D. (2007). Audience, authorship, and artefact: The emergent semiotics of Web 2.0. Annual Review of Applied Linguistics, 27, 1-23. http://dx.doi.org/10.1017/S0267190508070013

Young, D. J. (1992). Language anxiety from the foreign language specialist's perspective: Interviews with Krashen, Omaggio Hadley, Terrell, and Rardin. Foreign Language Annals, 25, 157-172. http://dx.doi.org/10.1111/j.1944-9720.1992.tb00524.x

Zhang, L. J. (2001). Exploring variability in language anxiety: Two groups of PRC students learning ESL in Singapore. RELC Journal, 32(1), 73-91. http://dx.doi.org/10.1177/003368820103200105

\section{Copyrights}

Copyright for this article is retained by the author(s), with first publication rights granted to the journal.

This is an open-access article distributed under the terms and conditions of the Creative Commons Attribution license (http://creativecommons.org/licenses/by/3.0/). 